Open Access at : http://jurnal.umt.ac.id/index.php/replik/index

\title{
PENYELENGGARAAN JAMINAN PRODUK HALAL BERDASARKAN UNDANG-UNDANG REPUBLIK INDONESIA NOMOR 33 TAHUN 2014 TENTANG JAMINAN PRODUK HALAL
}

\author{
Saan \\ Fakultas Hukum Universitas Universitas Pamulang \\ E mail : saanhasbi@yahoo.co.id
}

\begin{abstract}
Abstrak
Produk berupa makanan, minuman, obat, kosmetika, produk kimia, biologis dan rekayasa genetik, pada dasarnya dapat dikonsumsi oleh masyarakat sepanjang tidak terdapat larangan berdasarkan Syariat, dan saat ini persoalan halal dan haram bukan hanya merupakan isu yang sensitif di Indonesia, melainkan telah menjadi perhatian masyarakat internasional. Umat Islam di seluruh dunia amat berkepentingan atas jaminan halal tidak saja terhadap produk makanan, minuman, dan produk lainnya namun juga terhadap proses produksi serta rekayasa genetik. Pemerintah bertanggung jawab dalam menyelenggarakan Jaminan Produk Halal. Sebelum Undang-Undang Nomor 33 Tahun 2014 tentang Jaminan Produk Halal diterbitkan, sertifikat halal adalah fatwa tertulis yang dikeluarkan oleh MUI yang menyatakan kehalalan suatu produk sesuai dengan syari'at Islam. Saat ini dengan disahkannya Undang-Undang Nomor 33 Tahun 2014 ini maka penyelenggaraan Jaminan Produk Halal dilakukan oleh Badan Penyelenggara Jaminan Produk Halal, yang dalam melalaksanakan wewenangnya berkerjasama dengan kementerian dan/atau lembaga terkait, Lembaga Pemeriksa Halal, dan Majelis Ulama Indonesia. Tulisan ini memfokuskan pada masalah bagaimana Penyelenggaraan Jaminan Produk Halal berdasarkan Undang-Undang Nomor 33 Tahun 2014 tentang Jaminan Prdouk Halal dan Implementasinya saat ini, yang ternyata dalam pelaksanaannya memerlukan dukungan politik, koordinasi dan sinergi kebijakan dengan Kementerian/lembaga terkait serta para pemangku kepentingan (stake holder). Adanya sengketa kewenangan atau Tarik menarik kepentingan antara BPJPH dengan kementerian dan/atau lembaga lain hendaknya dilakukan dengan koordinasi yang lebih mendalam, salah satu caranya dengan memasukan solusi kewenangan itu dalam rancangan peraturan pemerintah.
\end{abstract}

Kata Kunci: Produk Halal, Jaminan Produk Halal, Penyelenggara Jaminan Produk Halal. 


\section{PENDAHULUAN}

\section{A. Latar Belakang}

Kebebasan untuk memeluk dan menjalankan ibadah agamanya masing-masing merupakan hak asasi yang dijamin pelaksanaanya dalam Undang-Undang Dasar Negara Republik Indonesia Tahun 1945, sebagaimana tercantum dalam Pasal 29 UndangUndang Dasar Negara Republik Indonesia Tahun 1945 bahwa negara berdasar atas Ketuhanan Yang Maha Esa dan negara menjamin kemerdekaan tiap-tiap penduduk untuk memeluk agamanya masing-masing dan untuk beribadat menurut agamanya dan kepercayaannya itu. Selain hak tersebut, setiap warga negara juga berhak mendapatkan perlindungan hukum, hak untuk mendapatkan kedudukan dalam hukum dan persamaan hak, serta hak untuk mendapatkan kehidupan yang layak. Hak Asasi tersebut merupakan cerminan dari kewajiban negara untuk melindungi segenap bangsa Indonesia dan seluruh tumpah darah Indonesia dan memajukan kesejahteraan umum sebagaimana diamanatkan dalam pembukaan Undang-Undang Dasar Negara Republik Indonesia Tahun 1945. Dengan demikian mengkonsumsi atau menggunakan produk yang halal menurut keyakinan agama dalam rangka menjamin kualitas hidup dan kehidupannya dapat dipandang sebagai bentuk hak warga negara yang dijamin oleh Undang-Undang Dasar Negara Republik Indonesia Tahun $1945 .^{1}$

Produk berupa makanan, minuman, obat, kosmetika, produk kimia, biologis dan rekayasa genetik, pada dasarnya dapat dikonsumsi oleh masyarakat sepanjang tidak terdapat larangan berdasarkan Syariat. Menurut ketentuan Syariat, seseorang harus bersipat hati-hati terhadap produk yang dikonsumsinya, karena dalam produk yang disangka halal kemungkinan terdapat bahan baku yang diharamkan, sehingga produk tersebut dianggap produk Syubhat, dengan demikian konsumen muslim harus berhatihati dalam memilih dan membeli produk tertentu untuk dikonsumsi atau menjauhi produk yang dianggap syubhat ${ }^{2}$.

Sebagai negara yang mayoritas penduduknya beragama Islam, maka tersedianya makanan minuman, obat, kosmetik, produk kimia biologi, dan produk rekayasa genetik yang terjamin kehalalannya menurut syariat bagi masyarakat Indonesia yang beragama

\footnotetext{
${ }^{1}$ Naskah Akademik Rancangan Undang-Undang Republik Indonesia tentang Jaminan Produk Halal yang dibuat DPR RI $h .1$

${ }^{2}$ Ibid
} 
Islam merupakan bagian yang tidak terpisahkan dari ibadah, sehingga produk yng dikonsumsi oleh masyarakat tersebut perlu dijamin kehalalannya ${ }^{3}$.

Persoalan halal dan haram bukan hanya merupakan isu yang sensitif di Indonesia, melainkan telah menjadi perhatian masyarakat internasional. Umat Islam di seluruh dunia amat berkepentingan atas jaminan halal tidak saja terhadap produk makanan, minuman, dan produk lainnya namun juga terhadap proses produksi serta rekayasa genetik. Terhadap produk dan rekayasa genetik dimaksud dibutuhkan respons normatif dari negara guna memenuhi kebutuhan hak konstitusional warga negara yang dijamin oleh UUD 1945 dan norma filosofis negara, Pancasila.

Berdasarkan fakta mengenai peredaran makanan, minuman di Indonesia, sertifikasi dan penandaan kehalalan suatu produk, baru menjangkau sebagian kecil produsen di Indonesia. Data Badan Pengawasan Obat dan Makanan (BPOM) Indonesia pada tahun 2005 menunjukkan bahwa tidak lebih dari 2.000 produk yang telah meminta pencantuman tanda halal. Sementara data dari LP POM Majelis Ulama Indonesia (MUI) menunjukkan bahwa sampai tahun 2010 telah berhasil mensertifikasi produk sebanyak 75.514, baik produk nasional maupun impor. Jumlah produk yang disertifikasi halal tahun 2010 sebanyak 21.837 produk, atau meningkat $100 \%$ dibandingkan tahun 2009 dan permohonan sertifikasi halal selama 11 tahun terakhir tidak lebih 8.000 produk dari 870 produsen di Indonesia ${ }^{4}$.

Respons positif terhadap kepentingan sertifikasi dan pencantuman tanda halal pada pangan dan produk lainnya telah dilakukan oleh Pemerintah Republik Indonesia dengan diterbitkannya beberapa peraturan perundang-undangan secara parsial, tidak konsisten, terkesan tumpang tindih, dan tidak sistemik yang berkaitan dengan sertifikasi dan pencantuman tanda halal. Oleh karena itu pengaturan demikian belum memberikan kepastian hukum dan jaminan hukum bagi umat Islam untuk mengenai pangan dan produk lainnya yang halal.

Undang-Undang Nomor 23 Tahun 1992 tentang Kesehatan, Undang-Undang Nomor 7 Tahun 1996 tentang Pangan, Undang-undang Nomor 6 Tahun 1967 tentang Ketentuan-ketentuan Pokok Peternakan dan Kesehatan Hewan, Undang-Undang Nomor

\footnotetext{
${ }^{3}$ Ibid, h. 2

${ }^{4}$ Agama, Kementerian, Laporan Hasil Penelitian Perilaku Komunitas Muslim Perkotaan Dalam Mengsumsi Produk Halal, Badan Litbang dan Diklat, 2011, h. 14.
} 
8 Tahun 1999 tentang Perlindungan Konsumen dan peraturan pelaksanaannya belum memberikan kepastian hukum dan jaminan hukum kepada umat Islam untuk mengenal pangan dan produk lainnya yang halal. Bagi Republik Indonesia sebagai negara yang mempunyai bagian terbesar warga negara dan penduduk yang beragama Islam, memberikan kepastian hukum dan jaminan hukum terhadap kehalalan pangan dan produk lainnya adalah conditio sine qua non.

Jaminan kehalalan suatu produk pangan dapat diwujudkan dalam bentuk sertifikat halal yang menyertai suatu produk pangan sehingga produsen dapat mencantumkan logo halal pada kemasannya ${ }^{5}$. Menanggapi kebutuhan tersebut dan didorong tanggung jawab untuk melindungi masyarakat, Majelis Ulama Indonesia (MUI) mendirikan Lembaga Pengkajian Pangan, Obat-obatan, dan Kosmetika MUI (LPPOM MUI) pada 6 Januari 1989 sebagai upaya untuk memberikan kepastian mengenai kehalalan suatu produk pangan, obat-obatan, dan kosmetika. Kegiatan sertifikasi halal LPPOM MUI terhadap produk pangan dimulai pada tahun 1994.

Sedangkan di sisi konsumen, pada tahun 1999 lahir Undang-Undang Nomor 8 tentang Perlindungan Konsumen yang memberikan perhatian mengenai jaminan produk halal (JPH). Dalam undang-undang tersebut, konsumen diberikan hak atas kenyamanan, keamanan, dan keselamatan dalam mengkonsumsi barang dan/atau jasa, serta memberikan kewajiban kepada pelaku usaha untuk memberikan informasi yang benar, jelas, dan jujur mengenai kondisi dan jaminan barang dan/atau jasa. Pelaku usaha juga dilarang memproduksi dan/atau memperdagangkan barang dan/atau jasa yang tidak mengikuti ketentuan berproduksi secara halal, sebagaimana pernyataan 'halal' yang dicantumkan dalam label.

Berbagai peraturan yang telah ada tersebut memang menyinggung mengenai Jaminan Produk Halal, namun dinilai masih bersifat ambiguous. Oleh karena itu pada tahun 2006, DPR RI melalui usul insiatif mengusulkan RUU tentang Jaminan Produk Halal. Setelah 8 tahun melalui pembahasan, RUU tersebut akhirnya dapat disahkan DPR menjadi Undang-Undang Nomor 33 Tahun 2014 tentang Jaminan Produk Halal (UU JPH) pada tanggal 17 Oktober 2014. Undang-Undang ini diharapkan dapat memberikan kepastian hukum bagi konsumen, khususnya masyarakat muslim sebagai konsumen 2003), h. 24.

\footnotetext{
${ }^{5}$ Anton Apriyantono dan Nurbowo, Panduan Belanja dan Konsumsi Halal, (Jakarta: Khairul Bayaan,
} 
terbesar.

Dalam Undang-Undang ini, penyelenggara Jaminan Produk Halal adalah Badan Penyelenggara Jaminan Produk Halal (BPJPH) bekerja sama dengan kementerian dan/atau lembaga terkait, LPH (Lembaga Pemeriksa Halal) dan MUI sebagai penerbit fatwa halal. BPJPH berada di bawah dan bertanggungjawab kepada Menteri Agama. Selain itu, UU ini memberikan kemudahan bagi pengusaha mikro mendapatkan bantuan dari APBN dan $\mathrm{APBD}^{6}$

Sebelum Undang-Undang Nomor 33 Tahun 2014 tentang Jaminan Produk Halal ini lahir, sertifikat halal adalah fatwa tertulis yang dikeluarkan oleh MUI yang menyatakan kehalalan suatu produk sesuai dengan syari'at Islam. Dalam upaya memenuhi harapan masyarakat muslim khususnya terhadap kepastian kehalalan produk makanan, sekarang dengan adanya Undang-Undang Nomor 33 Tahun 2014 ini maka wewenang ini dipegang oleh Badan Penyelenggara Jaminan Produk Halal. Hal ini sesuai dengan amanat undang-undangnya dan ini dikuatkan oleh Direktur Urusan Agama Islam dan Pembinaan Syariah, dimana menurut beliau "Badan Penyelenggara Jaminan Produk Halal (BPJPH) nanti memiliki kewenangan merumuskan dan menetapkan kebijakan Jaminan Produk Halal. "Selain itu juga menetapkan norma, standar, prosedur, dan kriteria jaminan produk halal," ungkap Direktur Urusan Agama Islam dan Pembinaan Syariah Kemenag RI, Muhammad Tambrin saat memberikan materi pada Workshop Jurnalistik yang digelar Pusat Informasi dan Kehumasan (PINMAS) Kementerian Agama RI di Gedung Kemenag RI Jl. Lapangan Banteng Barat ${ }^{7}$.

Adanya satu badan yang bertugas dan berfungsi untuk melakukan penyelenggaran Produk Halal adalah sebagai jawaban dari keresahan yang bagi masyarakat, adanya satu lembaga pemerintah, diharapkan proses pensertifikatan produk yang beredar di Indonesia akan bisa dilakukan dengan biaya murah. Dimana selama ini biaya yang tinggi menjadi kendala dan keluhan bagi sebagian besar produsen yang akan mendaftarkan produknya untuk mendapat sertifikat halal.

\footnotetext{
6“"UU Jaminan Produk Halal Berikan Kepastian Hukum Bagi

Konsumen",(http://www.hukumonline.com/berita/baca/lt54241d9c5a5ed/uu-jaminan-produk-halalberikankepastian-hukum bagi-konsumen, diakses 20 Februari 2017)

${ }^{7}$ Pusat Informasi dan Hubungan Masyarakat, Kementerian Agama tentang Wewenang Jaminan Produk Halal, Jakarta, 10 November 2016.
} 


\section{B. Perumusan Masalah.}

Untuk menghindari terlalu luasnya pembahasan ini dan berdasarkan latar belakang tersebut di atas, penulis hanya memfokuskan pada masalah bagaimana Penyelenggaraan Jaminan Produk Halal berdasarkan Undang-Undang Nomor 33 Tahun 2014 tentang Jaminan Produk Halal dan Implementasinya

\section{PEMBAHASAN}

\section{A. Pokok-pokok pengaturan dalam Undang-Undang Nomor 33 Tahun 2014 tentang Jaminan Produk Halal}

Pokok-pokok pengaturan dalam Undang-Undang Nomor 33 Tahun 2014 tentang Jaminan Produk Halal antara lain adalah sebagai berikut:

1. Untuk menjamin ketersediaan Produk Halal ditetapkan bahan produk yang dinyatakan halal, baik bahan yang berasal dari bahan baku hewan, tumbuhan, mikroba, maupun bahan yang dihasilkan melalui proses kimiawai, proses biologi, atau proses rekayasa genetik. Di samping itu, ditentukan pula PPH yang merupakan rangkaian kegiatan untuk menjamin kehalalan Produk yang mencakup penyediaan bahan, pengolahan, penyimpanan, pengemasan, pendistribusian, penjualan, dan penyajian Produk;

2. Undang-Undang ini mengatur hak dan kewajiban Pelaku Usaha dengan memberikan pengecualian terhadap Pelaku Usaha yang memproduksi Produk dari Bahan yang berasal dari Bahan yang diharamkan dengan kewajiban mencantumkan secara tegas keterangan tidak halal pada kemasan Produk atau pada bagian tertentu dari Produk yang mudah dilihat, dibaca, tidak mudah terhapus, dan merupakan bagian yang tidak terpisahkan dari Produk;

3. Dalam rangka memberikan pelayanan publik, Pemerintah bertanggung jawab dalam menyelenggarakan JPH yang pelaksanaannya dilakukan oleh BPJPH, dan dalam menjalankan wewenangnya, BPJH bekerja sama dengan kementerian dan/atau lembaga terkait, MUI, dan LPH

4. Tata cara memperoleh Sertifikat Halal diawali dengan pengajuan permohonan Sertifikat Halal oleh Pelaku Usaha kepada BPJPH. Selanjutnya, BPJPH melakukan 
pemeriksaan kelengkapan dokumen. Pemeriksaan dan/atau pengujian kehalalan Produk dilakukan oleh LPH. LPH tersebut harus memperoleh akreditasi dari BPJH yang bekerjasama dengan MUI. Penetapan kehalalan Produk dilakukan oleh MUI melalui sidang fatwa halal MUI dalam bentuk keputusan Penetapan Halal Produk yang ditandatangani oleh MUI. BPJPH menerbitkan Sertifikat Halal berdasarkan keputusan Penetapan Halal Produk dari MUI tersebut.

5. Biaya sertifikasi halal dibebankan kepada Pelaku Usaha yang mengajukan permohonan Sertifikat Halal. Dalam rangka memperlancar pelaksanaan penyelenggaraan JPH, Undang-Undang ini memberikan peran bagi pihak lain seperti Pemerintah melalui anggaran pendapatan dan belanja negara, pemerintah daerah melalui anggaran pendapatan dan belanja daerah, perusahaan, lembaga sosial, lembaga keagamaan, asosiasi, dan komunitas untuk memfasilitasi biaya sertifikasi halal bagi pelaku usaha mikro dan kecil.

6. Dalam rangka menjamin pelaksanaan penyelenggaraan JPH, BPJPH melakukan pengawasan terhadap LPH; masa berlaku Sertifikat Halal; kehalalan Produk; pencantuman Label Halal; pencantuman keterangan tidak halal; pemisahan lokasi, tempat dan alat pengolahan, penyimpanan, pengemasan, pendistribusian, penjualan, serta penyajian antara Produk Halal dan tidak halal; keberadaan Penyelia Halal; dan/atau kegiatan lain yang berkaitan dengan JPH.

7. Untuk menjamin penegakan hukum terhadap pelanggaran Undang-Undang ini, ditetapkan sanksi administratif dan sanksi pidana. ${ }^{8}$

Jaminan Produk Halal yang selanjutnya disingkat JPH memiliki arti suatu kepastian hukum terhadap kehalalan suatu produk yang dibuktikan dengan sertifikat halal $^{9}$. Berdasarkan pengertian tersebut maka dapat dipahami bahwa jaminan produk halal merupakan bagian yang tidak dipisahkan dari serangkaian proses untuk memperoleh sertifikat halal. Serangkaian proses untuk memperoleh sertifikat halal tersebut diawali dengan adanya penyelenggara jaminan produk halal yang berperan dalam proses tersebut dan terdapatnya bahan dan proses produk halal dalam hal memproduksi produk tersebut sehingga pada akhirnya memperoleh sertifikat halal.

Halal.

${ }^{8}$ Baca selanjutnya dalam penjelasan Undang-Udnang Nomor 33 Tahun 2014 tentang Jaminan Produk

${ }^{9}$ Undang-Undang Nomor 33 Tahun 2014 tentang Jaminan Produk Halal Pasal 1 angka 5 
Pengertian jaminan produk halal tidak jauh berbeda dengan pengertian sistem jaminan halal yang memiliki pengertian suatu sistem manajemen yang disusun, diterapkan dan dipelihara oleh perusahaan pemegang sertifikat halal untuk menjaga kesinambungan proses produksi halal sesuai dengan ketentuan LPPOM MUI ${ }^{10}$.

Seperti yang telah dijelaskan di atas bahwa jaminan produk halal merupakan suatu bentuk kepastian hukum terhadap kehalalan produk yang dibuktikan dengan sertifikat halal yang mana sertifikat halal tersebut dikeluarkan oleh Badan Penyelenggara Jaminan Produk Halal melalui fatwa tertulis MUI. Jaminan produk halal dengan sistem jaminan poduk halal hanya memiliki sedikit perbedaan dimana lembaga yang mengeluarkan sertifikat halal. Untuk lebih lanjut terkait dengan pihak yang mengeluarkan sertifikat halal dalam jaminan produk halal tersebut, dapat dilihat pada pembahasan berikutnya mengenai prosedur memperoleh sertifikat halal.

\section{B. Para Pihak Dalam Penyelenggaraan Jaminan Produk Halal}

\section{Badan Penyelenggara Jaminan Produk Halal}

Badan Penyelenggara Jaminan Produk Halal yang selanjutnya disingkat BPJPH adalah badan yang dibentuk oleh Pemerintah untuk menyelenggarakan Jaminan Porduk Halal disingkat $\mathrm{JPH}^{11}$. Dalam penyelenggaraan JPH, BPJPH berwenang $^{12}$ :

a. Merumuskan dan menetapkan kebijakan JPH;

b. Menetapkan norma, standar, prosedur, dan kriteria JPH;

c. Menerbitkan dan mencabut Sertifikat Halal dan Label Halal pada Produk.

d. Melakukan registrasi Sertifikat Halal pada Produk luar negeri.

e. Melakukan sosialisasi, edukasi, dan publikasi Produk Halal.

f. Melakukan akreditasi terhadap LPH.

g. Melakukan registrasi Auditor Halal.

h. Melakukan pengawasan terhadap JPH.

i. Melakukan pembinaan Auditor Halal.

\footnotetext{
${ }^{10}$ Lembaga Pengkajian Pangan, Obat-Obatan dan Kosmetika Majelis Ulama Indonesia, Panduan Umum Sistem Jaminan Halal LPPOM-MUI (Jakarta: LPPOM-MUI, 2008), hal. 7.

${ }^{11}$ Undang-Undang Nomor 33 Tahun 2014 tentang Jaminan Produk Halal Pasal 3.

12 1Undang-Undang Nomor 33 Tahun 2014 tentang Jaminan Produk Halal Pasal 5
} 
j. Melakukan kerja sama dengan lembaga dalam dan luar negeri di bidang penyelenggaraan JPH.

Dalam melaksanakan Wewenang tersebut, BPJPH bekerja sama dengan ${ }^{13}$ :

a. Kementerian dan/atau lembaga terkait;

b. LPH;

c. MUI

Kerja sama BPJPH dengan kementerian dan/atau lembaga terkait dilakukan sesuai dengan tugas dan fungsi kementerian dan/atau lembaga terkait antara lain Kementerian dan/atau lembaga yang menyelenggarakan urusan pemerintahan dibidang perindustrian, perdagangan, kesehatan, pertanian, standardisasi dan akreditasi, koperasi dan usaha mikro, kecil dan menengah, serta pengawasan obat dan makanan. Dalam penjelasan Pasal 8 Undang-Undang Nomor 33 Tahun 2014 tentang Jaminan Produk halal disebutkan bahwa:

a. Bentuk kerja sama BPJPH dengan kementerian yang menyelenggarakan urusan pemerintahan di bidang perindustrian misalnya dalam hal pengaturan serta pembinaan dan pengawasan industri terkait dengan bahan baku dan bahan tambahan pangan yang digunakan untuk menghasilkan Produk Halal.

b. Bentuk kerja sama BPJPH dengan kementerian yang menyelenggarakan urusan pemerintahan di bidang perdagangan misalnya dalam pembinaan kepada Pelaku Usaha dan masyarakat, pengawasan Produk Halal yang beredar di pasar, serta perluasan akses pasar.

c. Bentuk kerja sama BPJPH dengan kementerian yang menyelenggarakan urusan pemerintahan di bidang kesehatan misalnya dalam hal penetapan cara produksi serta cara distribusi obat, termasuk vaksin, obat tradisional, kosmetik, alat kesehatan, perbekalan kesehatan rumah tangga, makanan, dan minuman.

d. Bentuk kerja sama BPJPH dengan kementerian yang menyelenggarakan urusan pemerintahan di bidang pertanian misalnya dalam hal penetapan persyaratan rumah potong hewan/unggas dan unit potong hewan/unggas, pedoman pemotongan hewan/unggas dan penanganan daging hewan serta hasil ikutannya,

\footnotetext{
${ }^{13}$ Undang-Undang Nomor 33 Tahun 2014 tentang Jaminan Produk Halal Pasal 7
} 
pedoman sertifikasi kontrol veteriner pada unit usaha pangan asal hewan, dan sistem jaminan mutu dan keamanan pangan hasil pertanian.

e. Bentuk kerja sama BPJPH dengan lembaga pemerintah yang menyelenggarakan urusan pemerintahan di bidang standardisasi dan akreditasi misalnya dalam hal persyaratan untuk pemeriksaan, pengujian, auditor, lembaga pemeriksa, dan lembaga sertifikasi dalam sistem JPH sesuai dengan standar yang ditetapkan.

f. Bentuk kerja sama BPJPH dengan lembaga pemerintah yang menyelenggarakan urusan pemerintahan di bidang koperasi, usaha mikro, kecil, dan menengah misalnya dalam hal menyiapkan Pelaku Usaha mikro dan kecil dalam sosialisasi dan pendampingan sertifikasi kehalalan Produk.

g. Bentuk kerja sama BPJPH dengan lembaga pemerintah yang menyelenggarakan urusan pemerintahan di bidang pengawasan obat dan makanan misalnya dalam hal pengawasan produk pangan, obat, dan kosmetik dalam dan luar negeri yang diregistrasi dan disertifikasi halal.

Kerja sama BPJPH dengan LPH dilakukan untuk pemeriksaan dan/atau pengujian Produk. Kerja sama BPJPH dengan MUI dilakukan dalam bentuk ${ }^{14}$ :

a. sertifikasi Auditor Halal;

b. penetapan kehalalan Produk; dan

c. akreditasi LPH.

Pelaku usaha dalam mengajukan sertifikasi halal, BPJPH merupakan pihak yang diminta atas permohonan sertifikasi halal tersebut. Selain itu pula, BPJPH menetapkan Lembaga Pemeriksaan Halal atau yang disingkat dengan LPH untuk melakukan pemeriksaan dan/atau pengujian kehalalan Produk. Fungsi BPJPH yang lain adalah menetapkan bentuk Label Halal yang berlaku nasional.

Badan Penyelenggara Jaminan Produk Halal melakukan pengawasan terhadap JPH. BPJPH dan kementerian dan/atau lembaga terkait yang memiliki kewenangan pengawasan JPH dapat melakukan pengawasan secara sendiri-sendiri atau bersamasama. BPJPH dapat memberikan penghargaan kepada masyarakat yang berperan serta dalam penyelenggaraan JPH. BPJPH saat ini sudah dibentuk dengan Peraturan Presiden Nomor 83 Tahun 2015 tentang Organisasi Kementerian Agama dan hal ini

${ }^{14}$ Undang-Undang Nomor 33 Tahun 2014 tentang Jaminan Produk Halal Pasal 9 
sesuai Pasal 65 Undang-Undang Nomor 33 Tahun 2014 tentang Jaminan Produk Halal menyebutkan bahwa BPJPH dibentuk paling lama 3 (tiga) tahun terhitung sejak Undang-Undang Nomor 33 Tahun 2014 tentang Jaminan Produk Halal diudangkan.

\section{Majelis Ulama Indonesia}

Pasal 1 angka 7 Undang-Undang Nomor 33 Tahun 2014 tentang Jaminan Produk Halal menyebutkan bahwa Majelis Ulama Indonesia yang selanjutnya disingkat MUI adalah wadah musyawarah para ulama, zuama, dan cendekiawan muslim. MUI adalah Lembaga Swadaya Masyarakat yang mewadahi ulama, zu'ama, dan cendikiawan Islam di Indonesia untuk membimbing, membina dan mengayomi kaum muslimin di seluruh Indonesia. Majelis Ulama Indonesia berdiri pada tanggal, 7 Rajab 1395 Hijriah, bertepatan dengan tanggal 26 Juli 1975 di Jakarta, Indonesia ${ }^{15}$.

Momentum berdirinya MUI bertepatan ketika bangsa Indonesia tengah berada pada fase kebangkitan kembali, setelah 30 tahun merdeka, di mana energi bangsa telah banyak terserap dalam perjuangan politik kelompok dan kurang peduli terhadap masalah kesejahteraan rohani umat. Dalam perjalanannya, selama dua puluh lima tahun, Majelis Ulama Indonesia sebagai wadah musyawarah para ulama, zu'ama dan cendekiawan muslim berusaha untuk ${ }^{16}$ :

a. memberikan bimbingan dan tuntunan kepada umat Islam Indonesia dalam mewujudkan kehidupan beragama dan bermasyarakat yang diridhoi Allah Subhanahu wa Ta'ala;

b. memberikan nasihat dan fatwa mengenai masalah keagamaan dan kemasyarakatan kepada Pemerintah dan masyarakat, meningkatkan kegiatan bagi terwujudnya ukhwah Islamiyah dan kerukunan antar-umat beragama dalam memantapkan persatuan dan kesatuan bangsa serta;

c. menjadi penghubung antara ulama dan umaro (pemerintah) dan penterjemah timbal balik antara umat dan pemerintah guna mensukseskan pembangunan nasional;

d. meningkatkan hubungan serta kerjasama antar organisasi, lembaga Islam dan cendekiawan muslimin dalam memberikan bimbingan dan tuntunan kepada

\footnotetext{
${ }^{15}$ Anonim, “Sekilas MUI”, http://mui.or.id/sekilas-mui (diakses pada tanggal 20 April 2015).

${ }^{16}$ Ibid
} 
masyarakat khususnya umat Islam dengan mengadakan konsultasi dan informasi secara timbal balik. Lima Peran MUI.

Khittah pengabdian Majelis Ulama Indonesia telah dirumuskan lima fungsi dan peran utama MUI yaitu ${ }^{17}$ :

a. Sebagai pewaris tugas-tugas para Nabi (Warasatul Anbiya);

b. Sebagai pemberi fatwa (mufti);

c. Sebagai pembimbing dan pelayan umat (Ri' ayat wa khadim al ummah);

d. Sebagai gerakan Islah wa al Tajdid

e. Sebagai penegak amar ma'ruf nahi munkar.

Kerja sama BPJPH dengan MUI dilakukan dalam bentuk: a. sertifikasi Auditor Halal; b. penetapan kehalalan Produk; dan c. akreditasi LPH. Penetapan kehalalan Produk dikeluarkan MUI dalam bentuk Keputusan Penetapan Halal Produk. ${ }^{18}$

\section{Lembaga Pemeriksa Halal.}

Lembaga Pemeriksa Halal yang selanjutnya disingkat LPH adalah lembaga yang melakukan kegiatan pemeriksaan dan/atau pengujian terhadap kehalalan Produk. Fungsi dari LPH ini adalah bekerja sama dengan BPJPH untuk melakukan pemeriksaan dan atau pengujian produk. LPH dapat dibentuk oleh pemerintah ataupun masyarakat untuk membantu BPJPH untuk melakukan pemeriksaan dan atau pengujian kehalalan produk. Untuk mendirikan LPH, harus dipenuhi persyaratan ${ }^{19}$ :

a. memiliki kantor sendiri dan perlengkapannya;

b. memiliki akreditasi dari BPJPH;

c. memiliki Auditor Halal paling sedikit 3 (tiga) orang; dan

d. memiliki laboratorium atau kesepakatan kerja sama dengan lembaga lain yang memiliki laboratorium.

Lembaga Pemeriksa Halal yang didirikan oleh masyarakat, LPH harus diajukan oleh lembaga keagamaan Islam berbadan hukum, dan selama ini LPPOMMUI yang diberi kewenangan sebaga LPH.

\footnotetext{
${ }^{17}$ Undang-Undang Nomor 33 Tahun 2014 tentang Jaminan Produk Halal Pasal 1 angka 8.

${ }^{18}$ Undang-Undang Nomor 33 Tahun 2014 tentang Jaminan Produk Halal Pasal 7.

${ }^{19}$ Undang-Undang Nomor 33 Tahun 2014 tentang Jaminan Produk Halal Pasal 13 ayat 1
} 


\section{Auditor halal}

Auditor Halal adalah orang yang memiliki kemampuan melakukan pemeriksaan kehalalan Produk ${ }^{20}$.Auditor halal bekerja di dalam lembaga pemeriksa halal. Auditor Halal bertugas:
a. memeriksa dan mengkaji Bahan yang digunakan;
b. memeriksa dan mengkaji proses pengolahan Produk;
c. memeriksa dan mengkaji sistem penyembelihan;
d. meneliti lokasi Produk;
e. meneliti peralatan, ruang produksi, dan penyimpanan;
f. memeriksa pendistribusian dan penyajian Produk;
g. memeriksa sistem jaminan halal Pelaku Usaha; dan
h. melaporkan hasil pemeriksaan dan/atau pengujian kepada LPH

Berdasarkan tugas dan fungsinya, Auditor Halal diangkat oleh LPH harus memenuhi persyaratan ${ }^{21}$ :
a. warga negara Indonesia;
b. beragama Islam;
c. berpendidikan paling rendah sarjana strata 1 (satu) di bidang pangan, kimia, biokimia, teknik industri, biologi, atau farmasi;
d. memahami dan memiliki wawasan luas mengenai kehalalan produk menurut syariat Islam;

e. mendahulukan kepentingan umat di atas kepentingan pribadi dan/atau golongan; dan

f. memperoleh sertifikat dari MUI.

\section{Pelaku Usaha}

Pelaku Usaha adalah orang perseorangan atau badan usaha berbentuk badan hukum atau bukan badan hukum yang menyelenggarakan kegiatan usaha di wilayah Indonesia. Penyelia Halal adalah orang yang bertanggung jawab terhadap Proses Produk Halal.

\footnotetext{
${ }^{20}$ Undang-Undang Nomor 33 Tahun 2014 tentang Jaminan Produk Halal Pasal 1 angka 9

${ }^{21}$ Undang-Undang Nomor 33 Tahun 2014 tentang Jaminan Produk Halal Pasal 14
} 


\section{Penyelia Halal}

Penyelia Halal adalah orang yang bertanggung jawab penyelenggaran produk halal, dimana Penyelia Halal ini bertugas sebagai berikut:
a. mengawasi PPH di perusahaan;
b. menentukan tindakan perbaikan dan pencegahan;
c. mengoordinasikan $\mathrm{PPH}$; dan
d. mendampingi Auditor Halal LPH pada saat pemeriksaan.

Terdapat beberapa persyaratan Penyelia Halal dalam melaksakan tanggung jawab PPH,yaitu:
a. beragama Islam;
b. memiliki wawasan luas dan memahami syarat tentang kehalalan;
c. penyelia halal ditetapkan oleh pimpinan perusahaan dan dilaporkan kepada BPJPH.

\section{Bahan dan Proses Produk Halal}

Beberapa hal terpenting dalam suatu produk halal yang tidak dapat dilupakan adalah bahan dan bagaimana proses pengolahannya. Produk halal tidak dapat dipisahkan dari bahan-bahannya yang halal. Namun bahan halal saja tidak cukup, harus pula diikuti dengan prosesnya. Proses pembuatan produk halal haruslah benar-benar jauh dari hal-hal yang "berbau" haram dalam arti kata proses pengolahannya harus benar-benar bersih dari zat-zat yang dilarang dalam syariahIslam.

Bahan adalah unsur yang digunakan untuk membuat atau menghasilkan Produk. Bahan yang digunakan dalam proses produk halal terdiri atas bahan baku, bahan olahan, bahan tambahan, dan bahan penolong. Bahan yang dimaksud adalah hewan, tumbuhan, mikroba atau bahan yang dihasilkan melalui proses kimiawi, proses biologi, atau rekayasa genetik.

Bahan yang berasal dari hewan pada dasarnya halal, kecuali yang diharamkan menurut syariat. Bahan yang dari hewan yang diharamkan meliputi bangkai, darah, babi dan/atau hewan yang disembelih tidak sesuai dengan syariat.

Bahan yang berasal dari hewan yang diharamkan ditetapkan oleh Menteri 
berdasarkan fatwa MUI. Hewan yang digunakan sebagai bahan produk wajib disembelih sesuai dengan syariat dan memenuhi kaidah kesejahteraan hewan serta kesehatan masyarakat veteriner. Tuntunan penyembelihan dilaksanakan sesuai dengan ketentuan peraturan perundang-undangan.

Bahan yang berasal dari tumbuhan pada dasarnya halal, yang memabukkan dan/atau membahayakan kesehatan bagi orang yang mengonsumsinya. Bahan yang berasal dari mikroba dan bahan yang dihasilkan melalui proses kimiawi, proses biologi, atau proses rekayasa genetik diharamkan jika proses pertumbuhan dan/atau pembuatannya tercampur, terkandung, dan/atau terkontaminasi dengan bahan yang diharamkan. Bahan yang diharamkan ditetapkan oleh Menteri berdasarkan fatwa MUI.

Proses produk halal yang selanjutnya disingkat $\mathrm{PPH}$ adalah rangkaian kegiatan untuk menjamin kehalalan produk mencakup penyediaan bahan, pengolahan, penyimpanan, pengemasan, pendistribusian, penjualan, dan penyajian produk. Proses produk halal haruslah memiliki lokasi, tempat, dan alat PPH wajib dipisahkan dengan lokasi, tempat, dan alat penyembelihan, pengolahan, penyimpanan, pengemasan, pendistribusian, penjualan, dan penyajian produk tidak halal. Lokasi, tempat, dan alat PPH wajib dijaga kebersihan dan higienitasnya, bebas dari najis dan bebas dari bahan tidak halal.

Pelaku usaha yang tidak memisahkan lokasi, tempat, dan alat PPH dikenai sanksi administrasi berupa peringatan tertulis dan/aau denda administrasi.

Terkait akan hal bahan dan proses produk halal, MUI memuat beberapa ketentuan khusus yang harus dilakukan perusahaan diantaranya adalah:

1. Perusahaan harus jujur menjelaskan semua bahan yang digunakan dan proses produksi yang dilakukan di perusahaan serta melakukan operasional produksi halal sehari-hari.

2. Semua bahan yang digunakan dalam proses produksi halal harus pasti kehalalannya.

3. Sistem harus dapat mengidentifikasi setiap bahan secara spesifik merujuk pada pemasok, produsen, dan negara asal. Ini berarti bahwa setiap kode spesifik untuk satu bahan dengan satu status kehalalan.

4. Menyusun sistem pembuatan produk baru berdasarkan bahan yang telah disusun oleh KAHI dan diketahui oleh LPPOM MUI.

5. Menyusun sistem perubahan bahan sesuai dengan ketentuanhalal. 
6. Melaksanakan pemeriksaan terhadap setiap bahan yang masuk sesuai dengan sertifikat halal, spesifikasi dan produsennya.

7. Melakukan komunikasi dengan KAHI terhadap setiap penyimpangan dan ketidakcocokan bahan dengan dokumen.

8. Menyusun prosedur dan melaksanakan pembelian yang dapat menjamin konsistensi bahan sesuai dengan daftar bahan yang telah disusun oleh KAHI dan diketahui oleh LPPOM MUI.

9. Melakukan komunikasi dengan KAHI dalam pembelian bahan baru dan atau pemilihan pemasok baru.

10. Melakukan evaluasi terhadap pemasok dan menyusun peringkat pemasok berdasarkan kelengkapan dokumen halal.

11. Menyusun prosedur administrasi pergudangan yang dapat menjamin kehalalan bahan dan produk yang disimpan serta menghindari terjadinya kontaminasi dari segala sesuatu yang haram dan najis.

12. Melaksanakan penyimpanan produk dan bahan sesuai dengan daftar bahan dan produk yang telah disusun oleh KAHI dan diketahui oleh LPPOM MUI.

13. Melakukan komunikasi dengan KAHI dalam sistem keluar masuknya bahan dari dan ke dalam gudang.

Selain itu, MUI juga menetapkan ketentuan secara khusus kepada perusahaan dengan produk halal, yaitu:

1. Audit produk adalah audit yang dilakukan terhadap produk dengan melalui pemeriksaan proses produksi, fasilitas dan bahan-bahan yang digunakan dalam produksi produk tersebut.

2. Menyusun prosedur produksi yang dapat menjamin kehalalan produk.

3. Melakukan pemantauan produksi yang bersih dan bebas dari bahan haram dan najis.

4. Menjalankan kegiatan produksi sesuai dengan matrik formulasi bahan yang telah disusun oleh KAHI dan diketahui oleh LPPOM MUI.

5. Melakukan komunikasi dengan KAHI dalam hal proses produksi halal.

6. Menerapkan suatu Standard Operating Procedures (SOP) adalah suatu perangkat instruksi yang dibakukan untuk menyelesaikan suatu proses kerja rutin tertentu. SOP dibuat agar perusahaan mempunyai prosedur baku untuk mencapai tujuan penerapan SJH yang mengacu kepada kebijakan halal perusahaan. SOP dibuat untuk seluruh 
kegiatan kunci pada proses produksi halal yaitu bidang R\&D, Purchasing, QA/QC, PPIC, Produksi dan Gudang. Adanya perbedaan teknologi proses maupun tingkat kompleksitas di tiap perusahaan maka SOP di setiap perusahaan bersifat unik.

\section{Prosedur Memperoleh Sertifikat Halal.}

Pengaturan penggunaan produk halal di Indonesia memiliki dua hal yang saling terkait yaitu sertifikasi halal dan labelisasi ${ }^{22}$. Sertifikat halal adalah suatu fatwa tertulis dari Majelis Ulama Indonesia (MUI) yang menyatakan kehalalan suatu produk sesuai dengan syari'at Islam. Sertifikat halal ini merupakan syarat untuk mendapatkan ijin pencantuman label halal pada kemasan produk dari instansi pemerintah yang berwenang. Pengadaan sertifikasi halal pada produk pangan, obat-obat, kosmetika dan produk lainnya sebenarnya bertujuan untuk memberikan kepastian status kehalalan suatu produk, sehingga dapat menentramkan batin konsumen muslim. Namun ketidaktahuan seringkali membuat minimnya perusahaan memiliki kesadaran untuk mendaftarkan diri guna memperoleh sertifikat halal.

Adapun labelisasi halal adalah perizinan pemasangan kata "HALAL" pada kemasan prduk dari suatu perusahaan oleh Badan POM. Izin pencantuman label halal pada kemasan produk makanan yang dikeluarkan oleh Badan POM didasarkan rekomendasi MUI dalam bentuk sertifikasi halal MUI. Sertifikat halal MUI dikeluarkan oleh MUI berdasarkan hasil pemeriksaan LPPOM-MUI.

Namun sejak di terbitkannya Undang-Undang Nomor 33 Tahun 2014 tentang Jaminan Produk Halal akan ada perbedaan atas lembaga yang mengeluarkan sertifikat halal dan label halal. Berdasarkan Pasal 6 Undang-Undang Nomor 33 Tahun 2014 tentang Jaminan Produk Halal disebutkan bahwa Badan Penyelenggara Jaminan Produk Halal merupakan pihak yang berwenang untuk mengeluarkan sertifikat halal dan label halal. Akan tetapi peran MUI dalam hal untuk merekomendasikan atas sertifikat dan label halal tersebut masih ada dan tetap berperan.

Prosedur memperoleh sertifikat halal tercantum pada Pasal 29 ayat 1 dan 2 Undang-Undang Nomor 33 Tahun 2014 tentang Jaminan Produk Halal, disebutkan bahwa permohonan sertifikat halal diajukan oleh pelaku usaha secara tertulis kepada BPJPH.

\footnotetext{
${ }^{22}$ Zulham, Hukum Perlindungan Konsumen (Jakarta: Kencana Prenada Media Group, 2013), hal.112.
} 
Permohonan Sertifikat Halal harus dilengkapi dengan dokumen berupa data Pelaku Usaha, nama dan jenis produk, daftar produk dan bahan yang digunakan; dan proses pengolahan Produk.

Pada ayat 3 juga disebutkan bahwa ketentuan lebih lanjut mengenai tata cara pengajuan permohonan sertifikat halal diatur dalam Peraturan Menteri. Akan tetapi pada saat ini, Peraturan Menteri terkait dengan permohonan sertifikat halal belum dikeluarkan. Dalam Penjelasan Undang-Undang Nomor 33 Tahun 2014 tentang Jaminan Produk Halal pada poin 4 dan 5 disebutkan, bahwa:

1. Tata cara memperoleh Sertifikat Halal diawali dengan pengajuan permohonan Sertifikat Halal oleh Pelaku Usaha kepada BPJPH. Selanjutnya, BPJPH melakukan pemeriksaan kelengkapan dokumen. Pemeriksaan dan/atau pengujian kehalalan Produk dilakukan oleh LPH. LPH tersebut harus memperoleh akreditasi dari BPJH yang bekerjasama dengan MUI. Penetapan kehalalan Produk dilakukan oleh MUI melalui sidang fatwa halal MUI dalam bentuk keputusan Penetapan Halal Produk yang ditandatangani oleh MUI. BPJPH menerbitkan Sertifikat Halal berdasarkan keputusan Penetapan Halal Produk dari MUI tersebut.

2. Biaya sertifikasi halal dibebankan kepada Pelaku Usaha yang mengajukan permohonan Sertifikat Halal. Dalam rangka memperlancar pelaksanaan penyelenggaraan JPH, Undang-Undang ini memberikan peran bagi pihak lain seperti Pemerintah melalui anggaran pendapatan dan belanja negara, pemerintah daerah melalui anggaran pendapatan dan belanja daerah, perusahaan, lembaga sosial, lembaga keagamaan, asosiasi, dan komunitas untuk memfasilitasi biaya sertifikasi halal bagi pelaku usaha mikro dan kecil.

Selanjutnya, dalam Pasal 30 Undang-Undang Nomor 33 Tahun 2014 tentang Jaminan Produk Halal juga disebutkan bahwa BPJPH menetapkan LPH untuk melakukan pemeriksaan dan/atau pengujian kehalalan produk. Penetapan LPH sebagaimana dimaksud dilakukan dalam jangka waktu paling lama 5 (lima) hari kerja terhitung sejak dokumen permohonan sebagaimana dimaksud dalam Pasal 29 ayat (2) dinyatakan lengkap.

Pemeriksaan dan/atau pengujian kehalalan produk sebagaimana dimaksud dalam Pasal 30 di atas dilakukan oleh Auditor Halal. Pemeriksaan terhadap Produk dilakukan di lokasi usaha pada saat proses produksi. Dalam hal pemeriksaan produk terdapat bahan 
yang diragukan kehalalannya, dapat dilakukan pengujian di laboratorium. Dalam pelaksanaan pemeriksaan di lokasi usaha, pelaku usaha wajib memberikan informasi kepada Auditor Halal. LPH menyerahkan hasil pemeriksaan dan/atau pengujian kehalalan Produk kepada BPJPH. BPJPH menyampaikan hasil pemeriksaan dan/atau pengujian kehalalan produk kepada MUI untuk memperoleh penetapan kehalalan produk.

Setelah dilakukan pengujian dan pemeriksaan, maka selanjutnya adalah penetapan kehalalan produk. MUI dalam hal ini masih sebagai lembaga yang memiliki wewenang dalam melakukan penetapan kehalalan produk yang dimaksud, hal ini juga sesuai dengan Pasal 33 ayat 1 Undang-Undang Nomor 33 Tahun 2014 tentang Jaminan Produk Halal yang menyebutkan bahwa penetapan kehalalan produk dilakukan oleh MUI. Penetapan kehalalan produk sebagaimana dimaksud pada ayat (1) dilakukan dalam Sidang Fatwa Halal. Sidang Fatwa Halal MUI sebagaimana dimaksud pada ayat (2) mengikutsertakan pakar, unsur kementerian/lembaga, dan/atau instansi terkait. Sidang Fatwa Halal sebagaimana dimaksud pada ayat (3) memutuskan kehalalan Produk paling lama 30 (tiga puluh) hari kerja sejak MUI menerima hasil pemeriksaan dan/atau pengujian produk dari BPJPH. Keputusan Penetapan Halal Produk ditandatangani oleh MUI. Keputusan Penetapan Halal Produk disampaikan kepada BPJPH untuk menjadi dasar penerbitan sertifikat Halal.

Sidang Fatwa Halal yang dimaksudkan untuk menetapkan halal pada produk yang dimohonkan pelaku usaha, BPJPH akan menerbitkan sertifikat halal. Kemudian dalam hal Sidang Fatwa Halal menyatakan produk tidak halal, BPJPH mengembalikan permohonan sertifikat halal kepada pelaku usaha disertai dengan alasan sertifikat halal diterbitkan oleh BPJPH paling lama 7 (tujuh) hari kerja terhitung sejak keputusan kehalalan produk diterima dari MUI. Penerbitan sertifikat halal sebagaimana dimaksud dalam Pasal 35 wajib dipublikasikan oleh BPJPH.

Setelah pelaku usaha mendapatkan sertifikasi halal maka dalam hal ini pelaku usaha tersebut harus memiliki label halal. Label halal ditujukan untuk memberitahukan kepada masyarakat luas bahwa produk yang dimiliki pelaku usaha tersebut telah halal. Oleh karenanya label halal ini juga merupakan kewajiban yang harus dimiliki ketika pelaku usaha telah mendapatkan sertifikat halal.

Di dalam Pasal 1 angka 11 menyebutkan bahwa label halal merupakan tanda 
kehalalan suatu produk. Label halal itu sendiri ditetapkan bentuknya secara nasional oleh BPJPH, hal ini sesuai dengan Pasal 37 Undang-Undang Nomor 33 Tahun 2014 tentang Jaminan Produk Halal. Adapun jangka waktu label halal ini tercantum dalam suatu produk selama pelaku usaha memiliki sertifikat halal. Dengan demikian jangka waktu tersebut adalah selama 4 (empat) tahun.

Pengaturan pemberian jaminan produk halal pada dasarnya didasari dari Al-Quran dan Hadist. Kedua sumber hukum tersebut tidak dapat dipisahkan walaupun UndangUndang Nomor 33 Tahun 2014 disahkan. Undang-Undang Nomor 33 Tahun 2014 tentang Jaminan Produk Halal dapat dikatakan terobosan pengaturan di Indonesia terkait perlindungan umat Islam dalam mengkonsumsi produk-produk halal. Dengan demikian, legitimasi ini diharapkan benar-benar dapat memberikan penjelasan kepada para pelaku usaha bahwasannya produk halal sangat diutamakan oleh umat Islam.

\section{E. Implementasi Penyelenggaraan Jaminan Produk Halal}

Penerapan Undang-Undang Jaminan Produk Halal mengandung sejumlah substansi persoalan yang harus dituntaskan. Pengakuan bahwa agama merupakan pilar penting dalam kehidupan masyarakat dan negara diuji ketika berhadapan dengan kepentingan ekonomi dan bisnis. Suara-suara yang menolak UU JPH cukup nyaring terdengar yaitu meminta agar pemerintah merevisi UU JPH. Pihak yang merasa keberatan dengan beberapa pasal tertentu dalam UU JPH menganggap regulasi ini memberatkan pelaku dan dunia usaha serta berpotensi mengganggu iklim investasi di tanah air. Padahal tidak bakal terjadi gejolak yang mengganggu perekonomian nasional jika UU JPH diberlakukan.

Begitupula dalam penyusunan Rancangan Peraturan Pemerintah tentang Pelaksanaan Undang-Undang Nomor 33 Tahun 2014 tentang Jaminan Produk Halal yang saat ini sedang disusun terjadi tarik menarik kepentingan antara kementerian/lembaga terkait, terutama dalam merumuskan substansi yang akan diatur. Saat ini Rancangan Peraturan Pemerintah tentang Peraturan Pelaksanaan Undang-Undang Nomor 33 Tahun 2014 tentang Jaminan Produk Halal belum juga disahkan oleh Presiden.

Terdapat beberapa isu krusial dalam pembahasan Rancangan Peraturan Pemerintah tersebut, antara lain: 
1. Terkait pentahapan terhadap jenis produk yang bersertifikat halal yang wajib dilakukan secara bertahap berdasarkan amanah Pasal 67, UU No.33 Tahun 2014. Permasalahannya adalah dikarenakan jumlah produk halal yang banyak, sehingga untuk merumuskan kedalam norma RPP mengalami kesulitan, oleh karena itu ketentuan mengenai jenis produk yang bersertifikat halal perlu diatur dalam peraturan menteri, sedangkan Kementerian Perdagangan menghendaki agar rincian jenis produk wajib bersertifikat halal masuk dalam lampiran RPP JPH, serta persamaan persepsi terkait pentahapan terhadap produk yang bersertifikat halal. Permasalahan lainnya adalah Perbedaan pendapat terkait waktu penahapan terhadap produk yang bersertifikat halal, apakah setelah Oktober 2019 atau sebelum Oktober 2019 semua produk wajib bersertifikat halal.

2. Terkait dengan persamaan persepsi terhadap norma kewajiban bersertifikat halal, serta pencantuman "KeteranganTidak Halal" bagi produk yang bahan nya diharamkan atau tidak memenuhi proses produk halal. Permasalahannya adalah belum terjadinya persamaan persepsi terhadap norma "wajib bersertifikat halal" untuk produk yang masuk, beredar, serta diperdagangkan di Indonesia sebagaimana diamanahkan dalam ketentuan Pasal 4 UU No.33 Tahun 2014 serta pencantuman "Keterangan Tidak Halal" Bagi Produk yang berasal dari bahan yang diharamkan dan melalui proses yang tidak halal sebagaimana ketentuan Pasal 26 UU No.33 Tahun 2014.

4. Terkait Pendistribusian dan Penyajian Produk Halal dan produk yang tidak halal. Permasalahannya adalah untuk pendistribusian atau transfortasi terhadap produk yang halal dengan produk yang tidak halal apakah bisa disatukan dengan transfortasi yang sama, begitujuga terkait penyajian antara produk yang halal dan yang tidak halal harus dipisahkan penyajiannya.

5. Terkait Kerja sama Internasional. Permasalahannya adalah keinginan MUI untuk ikut dan terlibat dalam Kerja Sama Internasional.

Ombudusman Republik Indonesia (ORI) belum lama ini mengkritik pemerintah yang dianggap belum serius mempersiapkan pemberlakuan Undang-Undang Nomor 33 Tahun 2014 tentang Jaminan Produk Halal. Problem dasar sebetulanya adalah kesiapan infrastruktur kebijakan dan kesiapan dunia usaha dalam mengimplementasikan UU JPH. Dalam kaitan itu kesepahaman Kementerian Agama dengan MUI dan instansi terkait dengan implementasi UU JPH harus dibangun secara komprehensif. 
Kementerian Agama akan tetap mengimplementasikan UU JPH dan begitu juga DPR memandang tidak ada alasan bagi pemerintah untuk menunda penerapan UU JPH. Pada tataran operasional, Sertifikat Halal tidak hanya menyasar produk UKM, tetapi produk industri dan barang impor. Dalam UU JPH yang terdiri dari 68 pasal ini ditegaskan produk yang masuk, beredar dan diperdagangkan di wilayah Indonesia wajib bersertifikat halal. Pemerintah bertanggungjawab dalam menyelenggarakan Jaminan Produk Halal. Pemerintah sedang mengusahakan finalisasi Rancangan Peraturan Pemerintah tentang Pelaksanaan Undang-Undang Nomor 33 Tahun 2014 tentang Jaminan Produk Halal. Perangkat aturan pelaksana undang-undang JPH yang harus disiapkan cukup banyak. Pemerintah perlu membuat 7 Peraturan Pemerintah dan 11 Peraturan Menteri terkait dengan pelaksanaan UU JPH, diantaranya Peraturan Pemerintah tentang Pelaksanaan Undang-Undang JPH. Peraturan Pemerintah tentang Tarif Sertifikasi Halal, Peraturan Presiden tentang Organisasi dan Tata Kerja BPJPH, Peraturan Menteri Agama mengenai hal-hal teknis Penyelenggaraan Jaminan Produk Halal dan peraturan lainnya.

LPPOM MUI sebagai lembaga non pemerintah yang selama ini menangani sertifikasi halal, atau bisa dikatakan sebagai penjamin suatu kehalalan suatu produk. Harus beradabtasi paska lahirnya UU No. 33 Tahun 2014, Kewenangan MUI adalah memberikan fatwa penetapan kehalalan produk yang kemudian disampaikan kepada BPJPH sebagai dasar penerbitan Sertifikat Halal menurut ketentuan UU JPH, pelaku usaha yang telah memperoleh Sertifikat Halal wajib mencantumkan Label Halal pada kemasan produk, bagian tertentu dari produk dan/atau tempat tertentumpada produknya. Hal ini sesuai dengan Undang-Undang Nomor 33 Tahun 2014 tentang Jaminan Produk Halal bahwa kewenangan LPPOM MUI adalah LPH (Lembaga Pemeriksa Halal) dan mitra. Penjelasan selanjutnya dalam Pasal 10, bahwa kerja sama BPJPH dengan MUI/LPPOM MUI dilakukan dalam bentuk sertifikasi Auditor Halal, penetapan kehalalan produk dan akreditasi LPH.

Sertifikat Halal yang telah ditetapkan oleh MUI sebelum diberlakukannya UndangUndang Nomor 33 Tahun 2014 tentang Jaminan Produk Halal dinyatakan tetap berlaku sampai jangka waktunya habis. Undang-Undang ini juga menegaskan MUI tetap menjalankan tugasnya di bidang Sertifikat Halal sampai dengan BPJPH dibentuk. BPJPH sudah harus dibentuk paling lama 3 tahun terhitung sejak UU JPH diundangkan. Kementerian Agama sebagai leading sector sudah bergerak semenjak UU JPH 
diundangkan walaupun prosesnya tidak secepat yang diharapkan.

Dengan adanya Undang-Undang Nomor 33 Tahun 2014 tentang Jaminan Produk Halal, maka peluang untuk turut serta berpartisipasi dalam penanganan sertifikasi halal terbuka bagi ormas Islam yang berbadan hukum. Dengan ini akan terwujud perlindungan konsumen muslim di Indonesia terkait dengan kehalalan produk.

\section{SIMPULAN DAN SARAN}

Pelaksanaan Jaminan Produk Halal yang diamanatkan dalam UU JPH memerlukan dukungan politik, koordinasi dan sinergi kebijakan dari para pemangku kepentingan (stake holder). Sertifikasi halal diharapkan efektif dan massif menjangkau produk impor makanan, obat-obatan/farmasi dan kosmetika yang dijual di pasar-pasar swalayan dan tempat lainnya.

Di era pasar bebas dan keran impor yang kini dibuka lebar, pasar domestik dari waktu ke waktu kian dibanjiri produk makanan, obat-obatan/farmasi dan kosmetika yang belum dikenali kehalalannya, kondisi demikian menjadi sinyal kuat bahwa kita perlu meningkatkan "literasihalal" di masyarakat, seperti upaya meningkatkan literasi keuangan oleh Bank Indonesia dan Otoritas Jasa Keuangan. Tujuan yang dicapai tidak boleh berhenti pada ranah administrasi sertifikasi halal semata.

Adanya sengketa kewenangan antara BPJPH dengan lembaga lain hendaknya dilakukan dengan koordinasi yang lebih mendalam, salah satu caranya dengan memasukan solusi kewenangan itu dalam rancangan peraturan pemerintah yang sedang disusun, agar ketika BPJPH melakukan tugas dan fungsinya tidak saling memaksakan kewenangan, sehingga dalam tatanan implementasinya tidak membingungkan masyarakat, terutama pelaku usaha yang ingin mendaftarkan produknya karena dalam Undang-Undang Jaminan Produk Halal tersebut di tahun 2019 semua produk wajib bersertfikat halal.

Sambil terus menuju proses tersebut, mari kita kawal terus pelaksanaan UU Jaminan Produk Halal, sehingga dalam pelaksanaannya nanti tidak terlalu banyak masalah yang dihadapi, dan pelaksanaannya menyebar ke seluruh lapisan masyarakat, baik sebagai produsen maupun konsumen. Berkah dan kenyamanan dalam menggunakan produk barang dan jasa yang halal adalah daya Tarik utama bagi masyarakat, sehingga diharapkan melaluimmengenalkan manfaat gaya hidup halal-lah, jalan menuju masyarakat sadar halal 
semakin terbuka. Pada saatnya nanti perwujudan Indonesia sebagai surga halal dunia, akan segera terwujud.

\section{DAFTAR PUSTAKA}

\section{Buku :}

Agama, Departemen, Himpunan Fatwa Majelis Ulama Indonesia, Bagian Proyek Sarana dan Prasarana Produk Halal, Ditjen Bimas Islam, 2003.

Al-Asyhar, Thonieb, Bahaya Makanan Haram, Jakarta, Al Mawardi Prima. 2003

Anton Apriyantono dan Nurbowo, Panduan Belanja dan Konsumsi Halal, Jakarta: Khairul Bayaan, 2003

Ditjen Bimas Islam, Tanya Jawab Seputar Produksi Halal, Bagian Proyek Sarana dan Prasarana Produk Halal, 2003.

Ditjen Bimas Islam, Standar Jaminan Produk Halal Menurut Negara MABIMS, Proyek Pembinaan Produk Halal, 2004.

Jumanatul Ali, Al, Al-Qur'an dan Terjemahnya, Bandung, Departemen Agama RI, 2004.

Kementerian Agama, Perilaku Komunitas Muslim Perkotaan dalam Mengsumsi Produk Halal, Badan Litbang dan Diklat Puslitbang Kehidupan Keagamaan, 2013.

Kementerian Agama, Laporan Hasil Penelitian Perilaku Komunitas Muslim Perkotaan Dalam Mengosumsi Produk Halal, Badan Litbang dan Diklat, 2011.

Khallaf, Wahhab, Abdul, Ilmu Ushul Fiqih, Semarang, Dina Utama Semarang, 1994.

Pusat Informasi dan Hubungan Masyarakat, Kementerian Agama tentang Wewenang Jaminan Produk Halal, Jakarta, 10 November 2016.

Zulham, Hukum Perlindungan Konsumen, Jakarta: Kencana Prenada Media Group, 2013

Soekanto, Soerjono, Pengantar Penelitian Hukum, Jakarta, UI Press, 1984.

Lembaga Pengkajian Pangan, Obat-obatan dan Kosmetika Majelis Ulama Indonesia, Panduan Umum Sistem Jaminan Halal LPPOM-MUI, Jakarta: LPPOM-MUI, 2008.

\section{Undang-Undang :}

Undang-Undang Republik Indonesia Nomor 33 Tahun 2014 tentang Jaminan Produk Halal.

Undang-Undang Republik Indonesia Nomor 36 Tahun 2009 tentang Kesehatan.

Undang-undang Republik Indonesia Nomor 7 Tahun 1996 tentang Pangan.

Undang-Undang Republik Indonesia Nomor 8 Tahun 1999 tentang Perlindungan Konsumen.

Undang-Undang Republik Indonesia Nomor 6 Tahun 1967 tentang Ketentuan-ketentuan Pokok Peternakan dan Kesehatan Hewan. 
Naskah Akademik Undang-Undang Republik Indonesia Nomor 33 Tahun 2014 tentang Jaminan Produk Halal,

\section{Internet :}

UU Jaminan Produk Halal Berikan Kepastian Hukum Bagi Konsumen",(http://www.hukumonline.com/berita/baca/lt54241d9c5a5ed/uu-jaminanproduk-halal-berikankepastian-hukum

Anonim, "Sekilas MUI”, http://mui.or.id/sekilas-mui 